\title{
The Relationship among Service Quality, Relationship Quality, and Customer Loyalty for Chain Restaurant Industry
}

\author{
Jui-Lung Chen ${ }^{1}$ \\ ${ }^{1}$ Department of Business Administration, National Chin-Yi University of Technology, Taiwan, R.O.C. \\ Correspondence: Jui-Lung Chen, Department of Business Administration, National Chin-Yi University of \\ Technology, No.57, Sec. 2, Zhongshan Rd., Taiping Dist., Taichung 41170, Taiwan, R.O.C. Tel: \\ 886-4-2392-4505. E-mail: leonchen@ncut.edu.tw
}

Received: March 16, $2016 \quad$ Accepted: April 10, $2016 \quad$ Online Published: May 24, 2016
doi:10.5539/ijms.v8n3p33
URL: http://dx.doi.org/10.5539/ijms.v8n3p33

This research is supported by the National Chin-Yi University of Technology, Taiwan, R.O.C. (under Project\#: NCUT 16-T-MB-001).

\begin{abstract}
In an environment featuring fierce competition and consumers' ever higher requirements on service quality, the enterprises in the catering industry are facing unprecedented pressure in their survival. This study aims to explore the relevance among service quality, relationship quality and customer loyalty. With the customers of the Taiwanese chain stores in the catering industry as the research subjects, it collects data through questionnaire and analyzes the data with the descriptive statistics, the reliability and validity analysis, and the multiple regression analysis. The research results show that the "tangibles", "responsiveness" and "assurance" of service quality have effects on relationship quality. Moreover, the "assurance" of service quality and the "trust" and "commitment" have effects on customer loyalty. According to the research results, this study offers some reference to relevant enterprises and provides a direction for future studies.
\end{abstract}

Keywords: service quality, relationship quality, customer loyalty

\section{Introduction}

The economic growth, the industrial transformation, and the increasing number of people seeking employment and eating out have accelerated the development of the catering industry and contributed to a trend of fast advancement of the industry. With ever higher requirements and the expectation on customized and diverse services, customers have developed an increasing demand for high-quality products and services in the catering industry. Additionally, the contact between employees and customers, the service quality, and the employee performance play an essential role in the operation of enterprises in the industry; therefore, many enterprises invest a large quantity of resources to improve their services, so as to meet customer needs (Hsu, Chen, Chang, \& Chen, 2014). Against such a backdrop, how to improve services in the ever fierce competition is critical for the survival and effective operation of the enterprises (Parasuraman, Zeithaml, \& Berry, 1985).

The priority of enterprises is to attract customers (Porter, 1980). Customers are the core source of revenue and profit for enterprises; hence, enterprises must get acquainted with customer needs, manage to enhance customer value, focus on customer satisfaction and improve services (Day, 1990). Attaching importance to the relationship with customers and proposing the market strategies and implementation plans of enhancing customer value is an important principle of maintaining the relationship with customers. If enterprises establish a long-term relationship with customers, it will reduce the cost of transaction and the uncertainties in their future profits (Crosby, Evans, \& Cowles, 1990). In recent years, more attention has been paid to the operation concept of relationship quality in the catering industry. Relevant studies have demonstrated that a closer relationship with customers will lead to more benefits for enterprises in the catering industry (Reichheld \& Sasser, 1990). The low requirements on skill and capital, the low threshold, and the model easy to follow have resulted in extremely fierce competitions in the industry. Therefore, adopting the operation concept of relationship quality and fostering a sound relationship with customers will help customers reduce their cost and uncertainty in the transaction of products and services (Roberts, Varki, \& Brodie, 2003). Also, it will enable enterprises to reduce 
the cost of developing new customers, establish and maintain a sound and long-term relationship with customers, and increase profits (Hennig-Thurau, Gwinner, \& Gremler, 2002). According to Tellefsen and Thomas (2005), how to strengthen the relationship with customers and enhance the commitment to them is an important antecedent factor that influences transaction. Relationship quality determines the maintenance of the relationship between enterprises and customers, and only by keeping a long-range relationship with customers can enterprises gain a vantage point and make profits in competitions (Huang, Huang, Wu, \& Chang, 2014). In face of the fierce competitions and the transformation of the consumption pattern, how to maintain customer loyalty has become the most important topic about management in the catering industry in recent years. Customers are the most essential strategic resources of enterprises, so enterprises should concentrate on establishing customer loyalty and maintaining a long-term relationship with customers in marketing (Webster Jr., 1994). According to Selnes (1993), customer loyalty indicates customers' behavioral orientation for products and services and is an important factor that dominates the actual purchase behavior of customers. Moreover, loyal customers would not only increase sale and customer share but also reduce cost and raise price (Palmatier, Scheer, \& Steenkamp, 2007).

Based on the views and theories about service quality, relationship quality and customer loyalty, this study, with the customers of the Taiwanese chain stores in the catering industry as the research subjects, elaborates on the relevance among service quality, relationship quality and customer loyalty with the literature analysis and relevant statistical analysis. Here are the purposes of this study: (1) exploring the influence of service quality on relationship quality; (2) discussing the influence of service quality on customer loyalty; (3) delving into the influence of relationship quality on customer loyalty. According to the research results, this study gives some practical suggestions, with the hope of offering substantial help to the practitioners in the catering industry in their making operation strategies.

\section{Literature Review}

\subsection{Service Quality}

According to Zeithaml, Berry, \& Parasuraman (1996), service quality referred to customers' comment on the overall excellence of products or services. Lewis and Booms (1983) suggested that service quality was measured by the degree to which the services customers receive were in line with customers' expectation. Churchill \& Suprenant (1982) argued that service quality was the degree of customers' satisfaction with services and was determined by the gap between the actual services and the expected ones. Albert, Arthur, \& Pierre (2000) thought that service quality was the result of the comparison between the services customers expect and the perception customer had after receiving services. According to Lethinen \& Lethinen (1991), service quality derived from the interaction between customers and service providers and could be classified into process quality and output quality: process quality referred to customers' subjective remark on services, while output quality meant customers' measurement of service achievement. Bolton and Drew (1991), however, proposed that service quality could be divided into search quality, experience quality and credit quality. Ruihley \& Greenwell (2012) categorized service quality into seven dimensions, namely, interaction, actual facility, convenience, additional facilities, policies and rules, exercise, and others. Parasuraman et al. $(1985 ; 1988)$ defined service quality as the customers' comparison between the actual perceived services or experience quality and their expected services and called it "gap analysis". Then, he developed the 22-item SERVQUAL scale which was designed for objective measurement of service quality from five dimensions-tangibles, reliability, responsiveness, assurance and empathy.

\subsection{Relationship Quality}

Through effective relationship marketing, enterprises would obtain a high level of customer satisfaction and loyalty, and customers would develop a positive perception of product quality, which will enhance the profits of products (Evans \& Laskin, 1994). Relationship quality is a concept derived from relationship marketing. It means that a sound relationship is established with customers to reduce customers' uncertainty about transaction and foster customer loyalty, so that customers become reliant on or positive towards marketers, products or services (Smith, 1998). Smith (1998) defined relationship quality as an overall intensity that included various positive relations and the degree to which the demand and expectation of concerned parties were met. Service quality was an overall assessment on the intensity of the relationship between enterprises and customers, and the assessment met the demand and expectation of both parties (Storbacka, Strandvik, \& Grönroos, 1994). According to Storbacka et al. (1994), service quality involved customer satisfaction, relationship intensity, relationship life, and relationship profitability. Hennig-Thurau \& Klee (1997) argued that service quality depended on the degree to which enterprises satisfied customer needs: the more the relationship between 
customers and enterprises met customer needs, the higher relationship quality would become. Crosby et al. (1990) indicated that relationship quality is a concept consisting of trust and satisfaction: trust meant that customers had faith in marketers and thought that marketers considered customer interest and then took action on a long-term basis; satisfaction referred to the emotional expression in the assessment on interaction experience and the expectation that marketers could meet customer expectation. In his relationship quality model, Lagace, Dahlstrom, \& Gassenheimer (1991) also defined relationship quality from two perspectives - trust and satisfaction. Hsieh \& Hiang (2004) suggested that relationship quality was an advanced architecture and consisted of at least two dimensions - trust and satisfaction. According to Roberts et al. (2003), relationship quality comprised trust, satisfaction and commitment.

\subsection{Customer Loyalty}

Customer loyalty is a key factor in the creation of profits for service providers (Reynolds, Darden, \& Martin, 1974). Loyal customers purchase more, require a shorter service time, have a lower level of sensitivity to price, and bring new customers (Frederick \& Schefter, 2000). Neal (1999) proposed that customer loyalty referred to the proportion that customers still chose the same products or services after comparing them with that of other competitors when there was a convenient access to competitive products or services. Reichheld \& Schefter (2000) indicated that loyalty meant winning the trust from customers. According to Singh \& Sirdeshmukh (2000), customer loyalty referred to a behavioral tendency that customers were willing to maintain a relationship with enterprises, and it consisted of two dimensions - attitude and behavior. Fornell (1992) proposed that repurchase intention and satisfied customers' tolerance of price could be used to measure customer loyalty. Sirdeshmukh, Singh, \& Sabol (2002) mentioned that customer loyalty should include behavior (customers' behavior of repurchase) and attitude (customers' emotional cognition). Auh, Bell, McLeod, \& Shih (2007) indicated that loyalty should involve attitude loyalty and behavior loyalty: attitude loyalty indicated customers' intention of stay and their support for organizations, while behavior loyalty referred to the value customers were willing to repay to follow organizations. Gronholdt, Martensen, \& Kristensen (2000) classified customer loyalty into four aspects, namely, repurchase intention, recommendation, price tolerance, and cross-buying intention.

\subsection{The Relationship among Service Quality, Relationship Quality, and Customer Loyalty}

The service-based contact between customers and employees is often regarded as a "key moment" for creating service quality, and service quality is an essential antecedent variable that explains a long-term relationship (Hennig-Thurau et al., 2002; Lloyd \& Luk, 2011). Crosby et al. (1990) pointed out that service quality was a necessary condition for relationship quality. Lee (2015) delved into customers' views on the service quality of restaurants and explored the important factors that influenced customers' views on the service quality of restaurants. He found in his study that not all service quality factors could actually improve customers' views on the service quality of restaurants. Roberts et al. (2003) demonstrated in his study that service quality could have direct effects on relationship quality. Zeithaml (1981) thought that the relationship quality of buyers was measured by service providers' ability to reduce uncertainty and that a higher service quality indicated less uncertainty about service and a higher quality of the relationship between enterprises and customers. Hennig-Thurau et al. (2002) found that a higher service quality would lead to a higher relationship quality. Lo \& Huang (2014) used the PZB model to discuss the causal relationship between the service quality and customer satisfaction in the catering industry, and his analysis of the data showed that service quality had positive effects on customer satisfaction.

According to Zeithaml et al. (1996), customer loyalty was often adopted to review service quality, and the relevance between customer loyalty and service quality bore a close tie to the benefit-making of enterprises. Their study also demonstrated that service quality had significant positive effects on customer behavior intention. Keaveney (1995) found that good services would enhance customer satisfaction, foster a relationship between enterprises and customers, and make customers willing to continue the transaction with enterprises. Relationship quality is a key factor that determined the continual transaction between buyers and sellers (Anderson \& Sullivan, 1990). De Wulf, Oderkerken-Schroder, \& Iacobucci (2001) argued that relationship quality could strengthen customer loyalty. Lin, Tiao, Wang, \& Guo (2014) found that service quality, perceived value and recreational experience all had positive effects on customer satisfaction and loyalty. According to Tam \& Wong (2001), most of enterprises' business opportunities relied on relationship quality; relationship quality took an extremely critical part in relationship marketing and had effect on customer loyalty. Kumar, Scheer, \& Steenkamp (1995) proposed that a higher relationship quality would enhance the intention of continuing transaction and investment with enterprises. Andaleeb (1996) suggested that relationship quality is a key factor that determines the continual transaction between buyers and sellers. Park \& Kim (2001) indicated that relationship quality would affect customers' intention of purchasing other products and that only by ceaselessly improving the relationship with 
customers could enterprises achieve sustained customer loyalty (Grönroos, Heinonen, Isoniemi, \& Lindholm, 2000). Wang, Liang, \& Wu (2006) found that a higher relationship could contribute to a stronger customer loyalty. According to Chiou, Droge, \& Hanvanich (2002), a higher relationship quality had positive effects on customer loyalty. Li, Chen, Liu, \& Wang (2014) mentioned that the social responsibility and service quality of the enterprises in the catering industry created positive effects on customer loyalty and demonstrated that relationship quality played an intermediate role in the relationship.

According to the above literature, this study proposes the following hypotheses:

H1: Service quality has a significant positive effect on relationship quality.

H2: Service quality has a significant positive effect on customer loyalty.

H3: Relationship quality has a significant positive effect on customer loyalty.

\section{Research Methodological}

\subsection{Measurement Items}

(1) Service quality

The papers of various scholars are explored to know about their views on service quality. The SERVQUAL scale proposed by Parasuraman et al. (1985) has been widely applied to measure service quality. Therefore, the SERVQUAL scale revised by Parasuramanet al. (1991) was taken to measure service quality in the catering industry. In the scale, the five variables - tangibles, reliability, responsiveness, assurance and empathy were used to measure service quality in 22 items. The Likert 7-point scale was employed to measure these variables, and the assessment values ranged from "Strongly disagree" (1 point) to "Strong agree" (7 points). The respondents were asked to circle the ones according to their preference and the results were used to measure service quality.

(2) Relationship quality

Based on the views of Crosby et al. (1990) and Roberts et al. (2003), this study took trust, satisfaction and commitment as the three dimensions in the measurement of relationship quality in 10 items. The Likert 7-point scale was employed to measure these variables, and the assessment values ranged from "Strongly disagree" (1 point) to "Strong agree" ( 7 points). The respondents were asked to circle the ones according to their preference and the results were used to measure relationship quality.

\section{(3) Customer loyalty}

In this study, the four variables proposed by Gronholdt et al. (2000), namely, repurchase intention, recommendation, price tolerance, and cross-buying intention, were adopted to measure the dimension in 5 items. The Likert 7-point scale was employed to measure these variables, and the assessment values ranged from 1 (strongly disagree) to 7 (strong agree). The respondents were asked to circle the ones according to their preference and the results were used to measure customer loyalty.

(4) Basic personal information

This part consists of 5 items about gender, age, career, educational level, and monthly income.

\subsection{Research Structure}

This study elaborates on the relationship among the service quality, relationship quality and customer loyalty in the catering industry. To enhance the effectiveness of the questionnaire, 100 copies of questionnaire were distributed among the full-time students of the Department of Business Administration at a university in Taiwan. Then, the copies were retrieved for a pre-test analysis. According to the opinions on the pre-test, the ambiguous and ordinary items in the original draft were revised to achieve the final one. Due to the limited research cost and the timeliness, this study chose Taiwan as the research area and the customers of the Taiwanese enterprises in the catering industry as the research subjects. The convenience sampling was adopted in this study. Some work-study students were hired to stand at the entrances of several famous chain restaurants in Taiwan, distributing the copies of questionnaire among the customers who had finished their dinners in the restaurants and then retrieving the copies. In the process, 220 copies of questionnaire were distributed and retrieved. Of these 220 copies, 20 were invalid ones and were thus removed; the remaining 200 valid ones were kept. The rate of retrieving valid copies of questionnaire was about $91 \%$.

\section{Research Results}

\subsection{Descriptive Statistics}

According to the samples of this study, female respondents (57\%) surpassed male ones (43\%) in number; in 
terms of age, those aged 21-30 accounted for 51\%, followed by those aged 31-40 (20\%) and those aged over 41 $(19 \%)$; in terms of career, students made up $30 \%$, followed by those in the manufacturing industry $(27 \%)$ and those in the service industry $(25 \%)$; in terms of education, those with a college education, including undergraduates, accounted for $45 \%$, followed by those with a high school education or below (35\%); in terms of monthly income, those with less than USD 1,000 occupied $42 \%$, followed by those with more than USD 1,000 and less than USD 2,000 (26\%).

\subsection{Reliability and Validity}

Reliability aims to measure the consistency and stability of results, while validity refers to the degree to which measurement tools can really measure what researchers want to measure. In this study, Cronbach's $\alpha$ was adopted to measure reliability. According to Guilfold (1965), if a Cronbach's $\alpha$ was lower than 0.35, it indicated a low level of reliability and thus the questionnaire in question should be rejected; if a Cronbach's $\alpha$ was higher than 0.7, it indicated a high level of reliability; a Cronbach's $\alpha$ between 0.35 and 0.7 indicated an acceptable level of reliability. The Cronbach's $\alpha$ of the questionnaire of this study was 0.92 , and the Cronbach's $\alpha$ of all dimensions of the three variables - service quality, relationship quality and customer loyalty was above 0.7 , which indicated a high level of reliability in the measurement of the variables. Additionally, the variable measurement items in this study were based on the famous research scales and relevant studies. All these items were revised to meet the requirements of the catering industry; meanwhile, the questionnaire was assessed by some experts and pre-tested and was thus highly valid.

\subsection{Multiple Regression Analysis}

(1) The relationship between service quality and relationship quality: Table 1 shows that the prediction effects of service quality on overall relationship quality reached a significant level $(\mathrm{F}=63.360, \mathrm{p}<0.01)$. Three dimensions of service quality reached a significant level, including tangibles $(\beta=0.127, p<0.1)$, responsiveness $(\beta=0.127$, $\mathrm{p}<0.1)$ and assurance $(\beta=0.506, \mathrm{p}<0.01)$. Hence, Hypothesis 1 of this study is valid. In terms of the prediction effects on the dimension "trust" of relationship quality, two dimensions of service quality reached a significant level, including responsiveness $(\beta=0.252, p<0.01)$ and assurance $(\beta=0.424, p<0.01)$. In terms of the prediction effects on the dimension "satisfaction" of relationship quality, three dimensions of service quality reached a significant level, including tangibles $(\beta=0.190, \mathrm{p}<0.05)$, responsiveness $(\beta=0.143, \mathrm{p}<0.05)$ and assurance $(\beta=0.524, p<0.01)$. In terms of the prediction effects on the dimension "commitment" of relationship quality, two dimensions of service quality reached a significant level, including assurance $(\beta=0.465, p<0.01)$ and empathy $(\beta=0.156, \mathrm{p}<0.1)$.

Table 1. Regression analysis of the effects of service quality on relationship quality

\begin{tabular}{lllll}
\hline & & & \\
& & & & \\
Predictor Variable & & & Commitment & \\
\hline Tangibles & 0.033 & $0.190^{* *}$ & 0.130 & $0.127^{*}$ \\
Reliability & 0.041 & 0.012 & 0.040 & 0.034 \\
Responsiveness & $0.252^{* *}$ & $0.143^{* *}$ & -0.017 & $0.127^{*}$ \\
Assurance & $0.424^{* * *}$ & $0.524^{* * *}$ & $0.465^{* * *}$ & $0.506^{* * *}$ \\
Empathy & 0.082 & 0.036 & $0.156^{*}$ & 0.102 \\
F value & $56.653^{* * *}$ & $94.867^{* * *}$ & $42.668^{* * *}$ & $86.360^{* * *}$ \\
$\mathrm{R}^{2}$ & 0.594 & 0.710 & 0.524 & 0.690 \\
\hline
\end{tabular}

Note. Only standardized regression coefficient values $(\beta)$ are shown in the table; ${ }^{*} \mathrm{p}<0.10,{ }^{* *} \mathrm{p}<0.05, * * * \mathrm{p}<0.01$.

Table 2. Regression analysis of the effects of service quality on customer loyalty

\begin{tabular}{lllll}
\hline & Recommendation & Price tolerance & $\begin{array}{l}\text { Cross-buying } \\
\text { intention }\end{array}$ \\
Predictor Variable & Repurchase & Rerall customer loyalty & 0.103 \\
\hline Tangibles & 0.034 & 0.001 & 0.163 & $0.169 * *$ \\
Reliability & 0.172 & $0.178^{* *}$ & 0.059 & -0.033 \\
Responsiveness & -0.144 & -0.089 & -0.029 & -0.083 \\
Assurance & 0.185 & $0.595 * * *$ & $0.279 * * *$ & $0.763 * * *$ \\
Empathy & $0.318^{* * *}$ & -0.005 & 0.161 & -0.049 \\
F value & $15.300^{* * *}$ & $30.403 * * *$ & $20.046^{* * *}$ & $58.911 * * *$ \\
$\mathrm{R}^{2}$ & 0.283 & 0.439 & 0.341 & $0.509 * * *$ \\
\hline
\end{tabular}

\footnotetext{
Note. Only standardized regression coefficient values $(\beta)$ are shown in the table; ${ }^{*} \mathrm{p}<0.10,{ }^{* *} \mathrm{p}<0.05,{ }^{* * *} \mathrm{p}<0.01$.
} 
(2) The relationship between service quality and customer loyalty: Table 2 shows that the prediction effects of service quality on overall customer loyalty reached a significant level $(F=41.569, p<0.01)$. The dimension "assurance" $(\beta=0.509, \mathrm{p}<0.01)$ of service quality reached a significant level. Therefore, Hypothesis 2 of this study is valid. In terms of the prediction effects on the dimension "repurchase intention" of customer loyalty, the dimension "empathy" $(\beta=0.318, p<0.01)$ of service quality reached a significant level. In terms of the prediction effects on the dimension "recommendation" of customer loyalty, two dimensions of service quality reached a significant level, including reliability $(\beta=0.178, \mathrm{p}<0.05)$ and assurance $(\beta=0.595, \mathrm{p}<0.01)$. In terms of the prediction effects on the dimension "price tolerance" of customer loyalty, the dimension "assurance" $(\beta=0.279$, $\mathrm{p}<0.01$ ) of service quality reached a significant level. In terms of the prediction effects on the dimension "cross-buying intention" of customer loyalty, two dimensions of service quality reached a significant level, including tangibles $(\beta=0.169, \mathrm{p}<0.05)$ and assurance $(\beta=0.763, \mathrm{p}<0.01)$.

Table 3. Regression analysis of the effects of relationship quality on customer loyalty

\begin{tabular}{llllll}
\hline & Priterion Variable & $\begin{array}{l}\text { Repurchase } \\
\text { intention }\end{array}$ & Recommendation & Price tolerance & $\begin{array}{l}\text { Cross-buying } \\
\text { intention }\end{array}$ \\
\hline Predictor Variable & $0.302^{* * *}$ & $0.240^{* * *}$ & 0.051 & $0.298^{* * *}$ & $0.263^{* * *}$ \\
Satisfaction & $0.244^{* *}$ & 0.155 & 0.102 & $0.268^{* * *}$ & 0.060 \\
Commitment & $0.642^{* * *}$ & $0.400^{* * *}$ & $0.589^{* * *}$ & $0.279^{* * *}$ & $0.567^{* * *}$ \\
F value & $60.408^{* * *}$ & $79.272^{* * *}$ & $67.979^{* * *}$ & 105.833 & 152.262 \\
$\mathrm{R}^{2}$ & 0.480 & 0.548 & 0.510 & 0.6185 & 0.700 \\
\hline
\end{tabular}

Note. Only standardized regression coefficient values $(\beta)$ are shown in the table; ${ }^{*} \mathrm{p}<0.10, * * \mathrm{p}<0.05, * * * \mathrm{p}<0.01$.

(3) The relationship between relationship quality and customer loyalty: Table 3 shows that the prediction effects of relationship quality on overall customer loyalty reached a significant level $(\mathrm{F}=152.262, \mathrm{p}<0.01)$. Two dimensions of relationship quality reached a significant level, including trust $(\beta=0.263, p<0.01)$ and commitment $(\beta=0.567, p<0.01)$. Hence, Hypothesis 3 of this study is valid. In terms of the prediction effects on the dimension "repurchase intention" of customer loyalty, three dimensions of relationship quality reached a significant level, including trust $(\beta=0.302, \mathrm{p}<0.01)$, satisfaction $(\beta=0.244, \mathrm{p}<0.05)$ and commitment $(\beta=0.642, \mathrm{p}<0.01)$. In terms of the prediction effects on the dimension "recommendation" of customer loyalty, two dimensions of relationship quality reached a significant level, including trust $(\beta=0.240, p<0.01)$ and commitment $(\beta=0.400$, $\mathrm{p}<0.01)$. In terms of the prediction effects on the dimension "price tolerance" of customer loyalty, the dimension "commitment" $(\beta=0.589, \mathrm{p}<0.01)$ of relationship quality reached a significant level. In terms of the prediction effects on the dimension "cross-repurchase intention" of customer loyalty, three dimensions of relationship quality reached a significant level, including trust $(\beta=0.298, \mathrm{p}<0.01)$, satisfaction $(\beta=0.268, \mathrm{p}<0.05)$ and commitment $(\beta=0.279, \mathrm{p}<0.01)$.

\section{Conclusions and Recommendations}

\subsection{Conclusions}

The research results show that service quality had effects on both relationship quality and customer loyalty and that relationship quality had significant effects on customer loyalty. Additionally, the "tangibles", "responsiveness" and "assurance" of service quality had significant effects on relationship quality; the "assurance" of service quality had significant effects on customer loyalty; the "trust" and "commitment" of relationship quality had significant effects on customer loyalty.

\subsection{Managerial Implication}

According to the research purposes and the results of empirical analysis, the following management implications were proposed.

(1) The effects of service quality on relationship quality should be emphasized. Service quality has significant effects on relationship quality. A higher service quality can lead to a closer relationship with customers, so service quality is worthy of much attention from the enterprises in the catering industry. Particularly, the "tangibles", "responsiveness" and "assurance" of service quality are the most important for the overall relationship quality. Therefore, if customers feel that (a) a restaurant features an attractive appearance and great convenience, (b) the service providers offer timely and fast services and (c) the service providers are capable and polite and have relevant expertise and a strong ability to win the trust and confidence from customers, there will 
be a higher quality of relationship between the restaurant and customers. If customers feel that (a) the service providers offer timely and fast services and (b) the service providers are capable and polite and have relevant expertise and a strong ability to win the trust and confidence from customers, they will be more satisfied with the restaurant. If customers feel that (a) the service providers are capable and polite and have relevant expertise and a strong ability to win the trust and confidence from customers and (b) care and customized services are offered to customers, they will show greater commitment for the restaurant.

(2) The effects of service quality on customer loyalty should be emphasized. Service quality has significant effects on customer loyalty. A higher service quality can lead to stronger customer loyalty, and the dimension "assurance" of service quality has the greatest effect. Therefore, if customers feel that the service providers of a restaurant are capable and polite and have relevant expertise and a strong ability to win the trust and confidence from customers, they will be more loyal to the restaurant. If customers feel that the restaurant offers them care and customized services so that they feel the respect from the restaurant, they will develop a stronger repurchase intention. If customers feel that (a) the restaurant offers services in a reliable and correct way and (b) the service providers are capable and polite and have relevant expertise and a strong ability to win the trust and confidence from customers, they will be more likely to recommend the restaurant to others. If customers feel that the service providers are capable and polite and have relevant expertise and a strong ability to win the trust and confidence from customers, they will be more tolerant to price. If customers feel that (a) a restaurant features an attractive appearance and great convenience and (b) the service providers are capable and polite and have relevant expertise and a strong ability to win the trust and confidence from customers, they would have a stronger cross-buying intention.

(3) The effects of relationship quality on customer loyalty should be emphasized. Relationship quality has significant effects on customer loyalty. A higher relationship quality can lead to stronger customer loyalty, and the two dimensions of relationship quality, "trust" and "commitment", have the greatest effect. Therefore, if customers show more trust in a restaurant (trust in the intention or behavior of the restaurant and reliance on the transaction partner) and stronger commitment to the restaurant (both show behavior intention and interaction attitude in the future), they would be more loyal to the restaurant. If customers show more trust in a restaurant (trust in the intention or behavior of the restaurant and reliance on the transaction partner), more satisfaction with the restaurant (assessment of customers' preference for affairs relevant to consumption) and stronger commitment for the restaurant (both show behavior intention and interaction attitude in the future), they would have a stronger repurchase intention. If customers show more trust in a restaurant (trust in the intention or behavior of the restaurant and reliance on the transaction partner) and stronger commitment to the restaurant (both show behavior intention and interaction attitude in the future), they would be more likely to recommend it to others. If customers show stronger commitment to the restaurant (both show behavior intention and interaction attitude in the future), they would be more tolerant to price. If customers show more trust in a restaurant (trust in the intention or behavior of the restaurant and reliance on the transaction partner) and stronger commitment to the restaurant (both show behavior intention and interaction attitude in the future), they would be more likely to recommend it to others. If customers show stronger commitment to the restaurant (both show behavior intention and interaction attitude in the future), they would have a stronger cross-buying intention.

\subsection{Research Limitations and Future Studies Recommendations}

Due to the limited funds, manpower and time, this study merely covered Taiwan. Therefore, future studies can extend the research range to other countries to enhance the research accuracy. Moreover, only the catering industry was explored in this study, so the empirical results may not be applicable to other industries. Hence, future studies can focus on the consumers in other industries to know more about the relationship among service quality, relationship quality and customer loyalty in other industries.

\section{References}

Albert, C., Arthur, H. M., \& Pierre, R. B. (2000). Service quality and satisfaction: The moderating role of value. European Journal of Marketing, 34(11/12), 1338-1352. http://dx.doi.org/10.1108/03090560010764432

Andaleeb, S. S. (1996). An experimental investigation of satisfaction and commitment in marketing channels: The role of trust and dependence. Journal of Retailing, 72(1), 77-93. http://dx.doi.org/10.1016/S0022-4359(96)90006-8

Anderson, E. W., \& Sullivan M. W. (1990). Customer satisfaction and retention across firms. TIME College of Marketing Special Interest Conference on Service Marketing. TN: Nashville.

Auh, S., Bell, S., McLeod, C., \& Shih, E. (2007). Co-production and customer loyalty in financial services. 
Journal of Retailing, 83(3), 359-370. http://dx.doi.org/10.1016/j.jretai.2007.03.001

Bolton, R. N., \& Drew, J. H. (1991). A multistage model of consumers' assessments of service quality and value. Journal of Consumer Research, 17(4), 375-384. http://dx.doi.org/10.1086/208564

Chiou, J. S., Droge, C., \& Hanvanich, S. (2002). Does customer knowledge affect how loyalty is formed? Journal of Service Research, 5(2), 113-24.

Churchill, G. A., \& Surprenant, C. (1982). An Investigation into the determinants of consumer satisfaction. Journal of Marketing Research, 19(4), 491-504. http://dx.doi.org/10.2307/3151722

Crosby, L. A., Evans, K. R., \& Cowles, D. (1990). Relationship quality in services selling: An interpersonal influence perspective. Journal of Marketing, 54(3), 54-82. http://dx.doi.org/10.2307/1251817

Day, G. S. (1990). Market driven strategy: Processes for creating value. NY: The Free Press.

De Wulf, K., Oderkerken-Schroder, G., \& Iacobucci, D. (2001). Investment in consumer relationships: A cross-country and cross-industry exploration. Journal of Marketing, 65(4), 33-50. http://dx.doi.org/10.1509/jmkg.65.4.33.18386

Evans, J. R., \& Laskin, R. L. (1994). The Relationship marketing process: A conceptualization and application. Industrial Marketing Management, 23(5), 439-452. http://dx.doi.org/10.1016/0019-8501(94)90007-8

Fornell C. (1992). A national customer satisfaction barometer: The Swedish experience. Journal of Marketing, 56(1), 6-21. http://dx.doi.org/10.2307/1252129

Frederick, F. R., \& Schefter, P. (2000). E-Loyalty. Harvard Business Review, 4, 105-113.

Gronholdt, L., Martensen, A., \& Kristensen, K. (2000). The relationship between customer satisfaction and loyalty: Cross-industry differences. Total Quality Management and Business Excellence Journal, 11(4-6), 509-516. http://dx.doi.org/10.1080/09544120050007823

Grönroos, C., Heinonen, F., Isoniemi, K., \& Lindholm, M. (2000). The NetOffer model: A case example from

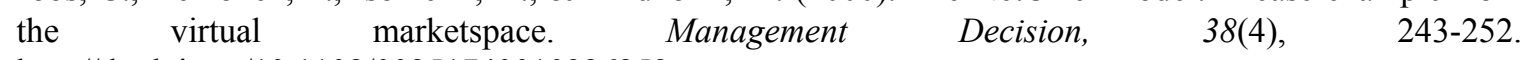
http://dx.doi.org/10.1108/00251740010326252

Guilfold, J. P. (1965). Fundemental statististics in psychology and education (4th ed.). NY: McGraw-Hill, Inc.

Hennig-Thurau, T., \& Klee, A. (1997). The impact of customer satisfaction and relatinship quality on customer retention: A critical reassessment and model development? Psychology \& Marketing, 14(8), 797-764. http://dx.doi.org/10.1002/(SICI)1520-6793(199712)14:8<737::AID-MAR2>3.0.CO;2-F

Hennig-Thurau, T., Gwinner, K. P., \& Gremler, D. D. (2002). Understanding relationship marketing outcomes: An integration of relational benefits and relationship quality. Journal of Service Research, 4(3), 230-247.

Hsieh, Y. C., \& Hiang, S. T. (2004). A study of the impacts of service quality on relationship quality in search-experience-credence services. Total Quality Management and Business Excellence Journal, 15(1), 43-58. http://dx.doi.org/10.1080/1478336032000149090

Hsu, S. W., Chen, S. Y., Chang, H. Y., \& Chen, Y. L. (2014). A study of organizational innovations, employee's job satisfaction and service quality in the international tourist hotels-human resource management system as a moderator. Commerce \& Management Quarterly, 15(4), 545-575.

Huang, Y. H., Huang, Y. A., Wu, M. H., \& Chang, Y. T. (2014). Antecedents and consequences of customer-employee rapport: An empirical investigation of Bed and Breakfast (B\&B) accommodations in Taiwan. Journal of Management (Taiwan), 31(4), 343-370. http://dx.doi.org/10.6504/JOM.2014.31.04.07

Keaveney, S. (1995). Customer switching behaviour in service industries: An exploratory study. Journal of Marketing, 59(2), 71-82. http://dx.doi.org/10.2307/1252074

Kumar, N., Scheer, L. K., \& Steenkamp, E. M. (1995). The effects of supplier fairness on vulnerable resellers. Journal of Marketing Research, 32(1), 54-65. http://dx.doi.org/10.2307/3152110

Lagace, R. R., Dahlstrom, R., \& Gassenheimer, J. B. (1991). The relevance of ethical salesperson behavior on relationship quality: The pharmaceutical industry. Journal of Personal Selling and Sale Management, 11(4), $39-47$.

Lee, H. (2015). Applying the Kano model of service quality in hotel management. Journal of Sport and Recreation Management, 12(1), 57-68. http://dx.doi.org/10.6214/JSRM.1201.004

Lehtinen, U., \& Lehtinen, J. (1991). Two approaches to service quality dimensions. The Service Industries 
Journal, 11(3), 287-303. http://dx.doi.org/10.1080/02642069100000047

Lewis, R. C., \& Booms B. H. (1983). The marketing aspects of service quality. In L. Berry, G. Shostak, \& G. Upah (Eds.), Emerging Perspectives on Services Marketing (pp. 99-107). Chicago: American Marketing Association.

Li, C. C., Chen, H. H., Liu, J. S., Wang, C. C. (2014). The relationship among corporate social responsibility, service quality, consumer relationship quality, and loyalty: A case study of hospitality industry in Taiwan. Journal of Island Tourism Research, 7(2), 1-31.

Lin, F. J., Tiao, L. Y., Wang, Z. H., Guo, Y. R. (2014). Effects of service quality, perceived service value, and recreation experience on satisfaction and loyalty: A case of Pingtung Wanluan Hillside Leisure Agricultural Area. Journal of the Agricultural Association of Taiwan, 15(2), 164-194.

Lloyd, A. E., \& Luk, S. T. K. (2011). Interaction behaviors leading to comfort in the service encounter. Journal of Services Marketing, 25(3), 176-189. http://dx.doi.org/10.1108/08876041111129164

Lo, C. H., \& Huang, S. H. (2014). PZB model to investigate the service quality and customer satisfaction between the causal relationship in food and beverage industry. Journal of Sport, Leisure and Hospitality Research, 9(3), 1-22.

Neal, W. D. (1999). Satisfaction is nice, but value drives loyalty. Marketing Research, 1, 21-23.

Palmatier, R. W., Dant, R. P., \& Grewal, D. (2007). A comparative longitudinal analysis of theoretical perspectives of interorganizational relationship performance. Journal of Marketing, 71(4), 172-194. http://dx.doi.org/10.1509/jmkg.71.4.172

Parasuraman, A., Zeithaml, V. A., \& Berry, L. L. (1985). A conceptual model of service quality and its implications for future research. Journal of Marketing, 49(3), 41-50. http://dx.doi.org/10.2307/1251430

Parasuraman, A., Zeithaml, V. A., \& Berry, L. L. (1988). Communication and control processes in the delivery of service quality. Journal of Retailing, 64(1), 12-40. http://dx.doi.org/10.2307/1251263

Park, J. W., \& Kim, K. H. (2001). Role of consumer relationship with a brand in brand extensions: Some exploratory findings. Advances in Consumer Research, 28, 179-185.

Porter, M. (1980). Competitive strategy. NY: The Free Press.

Reichheld, F. F., \& Sasser, W. E. (1990). Zero defection: Quality comes to services. Harvard Business Review, 68(5), 105-111.

Reichheld, F. F., \& Schefter, P. (2000). E-Loyalty, Harvard Business Review, 78(4), 105-114.

Reynolds, F. D., Darden, W. R., \& Martin, W. (1974). Developing an image the store-loyal customer. Journal of Retailing, 50(4), 73-84.

Roberts, K., Varki, S., \& Brodie, R. (2003). Measuring the quality of relationships in consumer services: An empirical study. European Journal of Marketing, 37(1/2), 169-196. http://dx.doi.org/10.1108/03090560310454037

Ruihley, B., \& Greenwell, T. C. (2012). Understanding the league sport participation experience utilizing the critical incident technique. Sport Marketing Quarterly, 21, 32-42.

Selnes, F. (1993). An examination of effect of product performance on brand reputation, satisfaction and loyalty. European Journal of Marketing, 27(9), 19-35. http://dx.doi.org/10.1108/03090569310043179

Singh, J., \& Sirdeshmukh, D. (2000). Agency and trust mechanisms in consumer satisfaction and loyalty judgments. Academy of Marketing Science, 28(1), 150-167.

Sirdeshmukh, D., Singh, J., \& Sabol, B. (2002). Consumer trust, value, and loyalty in relational exchanges. Journal of Marketing, 66(1), 15-38.

Smith, B. (1998). Buyer-seller relationships: Bonds, relationship management and sex-type. Canadian Journal of Administrative Sciences, 15(1), 76-92. http://dx.doi.org/10.1111/j.1936-4490.1998.tb00153.x

Storbacka, K., Strandvik, T., \& Grönroos, C. (1994). Managing customer relationships for profit: The dynamics of relationship quality. International Journal of Service Industry Management, 5(5), 21-38. http://dx.doi.org/10.1108/09564239410074358

Tam, J., \& Wong, Y. (2001). Interactive selling: A dynamic framework for services. Journal of Service Marketing, 15(5), 379-396. http://dx.doi.org/10.1108/EUM0000000005656 
Tellefsen, T., \& Thomas, G. P. (2005). The antecedents and consequences of organizational and personal commitment in business service relationships. Industrial Marketing Management, 34(1), 23-37. http://dx.doi.org/10.1016/j.indmarman.2004.07.001

Wang, W. H., Liang, C. J., \& Wu, Y. D. (2006). Relationship bonding tactics, relationship quality and customer behavioral loyalty-behavioral sequence in Taiwan's information services industry. Journal of Services Research, 6(1), 31-57.

Webster, Jr. F. E. (1994). Defining the new marketing concept. MarketingManagement, 2(4), $22-31$.

Zeithaml, V. A. (1981). How Consumer Evaluation Processes Differ between Goods and Services. Reprinted in Lovelock, C., Services Marketing (2nd ed.). Upper Saddle River, New Jersey: Prentice Hall.

Zeithaml, V. A., Berry, L. L., \& Parasuraman, A. (1996). The behavioral consequences of service quality. Journal of Marketing, 60(2), 31-46. http://dx.doi.org/10.2307/1251929

\section{Copyrights}

Copyright for this article is retained by the author(s), with first publication rights granted to the journal.

This is an open-access article distributed under the terms and conditions of the Creative Commons Attribution license (http://creativecommons.org/licenses/by/3.0/). 